\title{
Detection of anti-Leptospira spp., anti-Brucella spp., and anti- Toxoplasma gondii antibodies in stray dogs
}

\section{Detecção de anticorpos anti-Leptospira spp., anti-Brucella spp., and anti-Toxoplasma gondii em cães errantes}

\author{
Danieli Cristiane Martins Hafemann ${ }^{1}$; Luiz Sérgio Merlini2² \\ Daniela Dib Gonçalves²; Maira Salomão Fortes ${ }^{4}$; \\ Italmar Teodorico Navarro ${ }^{3}$; Roberta Torres Chiderolli $;$; Julio Cesar Freitas ${ }^{3}$; \\ Arianne Peruzo Pires Gonçalves ${ }^{1}$; Gilneia Rosa ${ }^{6}$; Paulo Henrique Sposito ${ }^{6}$
}

\begin{abstract}
Dogs can act as intermediary hosts, reservoirs, and sentinel animals for zoonotic diseases such as brucellosis, toxoplasmosis and leptospirosis, and human contact with domestic animals can spread these infections. These diseases are globally distributed, and are a uniquely severe health issue, since they can infect a great range of animals, including humans. The purpose of this work was to determine the prevalence of anti-Leptospira spp., anti-Brucella spp., and anti-Toxoplasma gondii antibodies in stray dogs. Blood samples were collected from 181 stray dogs and used for serological diagnosis. Of the analyzed samples, $36.46 \%, 16.57 \%$, and $9.39 \%$ were positive for T. gondii, Leptospira spp., and B. canis. The results indicate that these zoonotic diseases are highly prevalent in stray dogs in the northwestern region of the state of Paraná. The high infection rates for these zoonotics in the canine population is an indication that the environment is contaminated with a variety of different microorganisms, exposing both humans and dogs to different sources of infection.
\end{abstract}

Key words: Brucella canis. Dogs. Leptospira spp. Toxoplasma gondii. Public health.

\section{Resumo}

O contato do homem com alguns animais domésticos faz com que algumas zoonoses como brucelose, toxoplasmose e leptospirose, tornem-se infecções importantes e, com isso os cães atuam como hospedeiros intermediários, reservatórios e animais sentinelas para estas infecções. Essas enfermidades tem distribuição mundial, e é um grave problema de saúde pública, podendo infectar uma grande variedade de animais, entres os quais, se destacam o cão e o homem. O objetivo deste trabalho foi detectar a ocorrência de anticorpos contra Leptospira spp., Brucella spp. eToxoplasma gondii em cães

${ }^{1}$ Médicas Veterinárias, Discentes, Programa de Pós-Graduação em Ciência Animal, Universidade Paranaense, UNIPAR, Umuarama, PR, Brasil. E-mail: danihafemann@hotmail.com; arianneppg@gmail.com

2 Médicas Veterinárias, Programa de Pós-Graduação em Ciência Animal, UNIPAR, Umuarama, PR, Brasil. E-mail: danieladib@, prof. unipar.br; merlini@prof.unipar.br

${ }_{3}^{3}$ Médico Veterinário. Programa de Pós-Graduação em Ciência Animal, Universidade Estadual de Londrina, UEL, Londrina, PR, Brasil. E-mail: italmar@uel.br; freitasj@uel.br

${ }^{4}$ Médica Veterinária, Bolsista PNPD/CAPES, Programa de Pós-Graduação em Ciência Animal, Universidade Paranaense, UNIPAR, Umuarama, PR, Brasil. E-mail: maíra_salomao@yahoo.com.br

5 Médica Veterinária, Discente de Doutorado, Programa de Pós-Graduação em Ciência Animal, UEL, Londrina, PR, Brasil. E-mail: ro.vetuel@gmail.com

${ }^{6}$ Discentes, Universidade Paranaense, UNIPAR, Umuarama, PR, Brasil. E-mail: gilneia.medvet@gmail.com; paulohsposito@ gmail.com

* Author for correspondence 
errantes Amostras de sangue colheram amostras de sangue de 181 cães errantes para a realização dos diagnósticos sorológicos. Das amostras analisadas, 36,46\% foram reagentes para Tgondii, 16,57\% para Leptospira spp. e9,39\% para Brucella canis.A partir dos resultados obtidos no presente trabalho, verificou-se que essas zoonoses apresentam elevadaprevalência nos cães errantes do estudo. O elevado índice de infecção da população canina para estas zoonoses, torna-seum indicativo de que o ambiente está contaminado com diferentes micro-organismos representando um problema para a saúde única, uma vez que tanto o homem como o cão estão expostos a diferentes fontes de infecção.

Palavras-chave: Brucella canis. Canídeos. Leptospira spp. Toxoplasma gondii. Saúde pública.

\section{Introduction}

Stray animals are an important population in veterinary medicine, as their ease of contamination and lack of prophylactic measures make them ideal reservoirs, allowing the maintenance of infectious agents and their dispersion to non-endemic areas. This population is increasing, and direct and indirect contact with humans occurs rather easily. Inappropriate diet and absence of hygienic care and shelter make stray animals susceptible to different diseases, and they may exhibit less effective immune responses, with more intense clinical profiles compared to domesticated dogs (MAGALHÃES; MATEUS, 2012).

Human contact with domestic animals can render some zoonotic diseases, such as brucellosis, toxoplasmosis, and leptospirosis, significant infections, with dogs acting as intermediary hosts, reservoirs, and sentinel animals (ARAÚJO et al., 2011). These three zoonotics have global distribution and may infect a great variety of domestic and wild animals, as well as humans (DANTAS et al., 2014).

Dogs living in the outskirts of urban areas, where hygiene, sanitation, and infrastructure are precarious, and interactions with other animal species are highly probable, are an at-risk population for several different diseases (GENOVEZ, 1996). In urban areas, dogs considered stray (those with no owners or whose owners are negligent), have a 3.59-fold greater risk of being infected with diseases, due to exposure to standing water and garbage-sourced food that can be contaminated by the urine from rodents or other infected animals. The congregation of stray dogs when the females are in heat compounds the problem (MAGALHÃES et al., 2007).
In Brazil, different studies have examined the seroprevalence of leptospirosis, brucellosis, and toxoplasmosis in stray dogs in the states of São Paulo (MALEK et al., 2008); Minas Gerais (SOUZA PINTO, et al., 2004); Bahia (JESUS et al., 2006); Pará (VALADAS et al., 2010); Santa Catarina (BLAZIUS et al., 2005); and Minas Gerais (CASTRO et al., 2011). The prevalence rates reported in seroepidemiological studies of stray dogs may help clarify the epidemiology of these diseases in different regions and promote the adoption of preventive measures for the general population.

Toxoplasmosis is a serious public health issue. It is an important clinical disease in high-risk groups, mainly pregnant women and immune-deficient individuals (DANTAS et al., 2014). Infection can occur through the ingestion of contaminated food or water, or the ingestion of raw or undercooked meat containing cysts of the infective agent (ARAÚJO et al., 2011). Dogs play an important role in the epidemiology of this disease, since they are used as sentinels for toxoplasmosis (SILVA et al., 2009; DANTAS et al., 2014). Similar to that in humans, infection of dogs with Toxoplasma gondii is generally asymptomatic, and epidemiological surveys in dogs have shown that age, access to the street, and type of dwelling are related to higher infection rates (ARAÚJO et al., 2011).

Similar to toxoplasmosis, leptospirosis is an important zoonotic disease and a severe global public health issue. The disease affects both rural and urban areas, and has caused epidemics in several countries, including Brazil (BIER et al., 2013). The outbreaks are caused by exposure to water contaminated with urine or tissue from infected animals, and increase 
during periods with high rainfall (BATISTA et al., 2004a). Dogs play an important role in leptospirosis epidemiology, owing to their proximity to humans. They can eliminate live leptospira through their urine for several months without presenting clinical signs of the disease (QUERINO et al., 2003). Dogs can be infected by exposure to other contaminated dogs, as well as by rats that urinate in common areas.

Canine brucellosis, a zoonotic disease caused by various Brucella species, is currently of great concern to public health (AZEVEDO et al., 2004), and is mainly transmitted by contact between dogs and children. Although the main etiological agent of canine brucellosis is $B$. canis, dogs may also be infected with B. abortus, B. suis, or B. melitensis, becoming potential sources of infection for other animals and humans (OLIVEIRA et al., 2011).
The purpose of this work was to detect anti-T. gondii, anti-Leptospira spp. and anti-B. canis antibodies in stray dogs.

\section{Materials and Methods}

\section{Study location and collection of samples}

Blood samples were collected from stray dogs that were captured and housed in private shelters located in the urban areas in the cities of Assis Chateaubriand, São Jorge do Patrocínio, Pérola, Umuarama, Marechal Cândido Rondon, Moreira Sales, and Paranavaí, all located in the northwestern and western regions of the state of Paraná, Brazil (Figure 1). These shelters are philanthropic organizations that remove stray dogs from the streets and take them to a location where they receive shelter, food, and water, awaiting future adoption.

Figure 1. Northwestern and Western micro-regions of the state ofin Paraná.

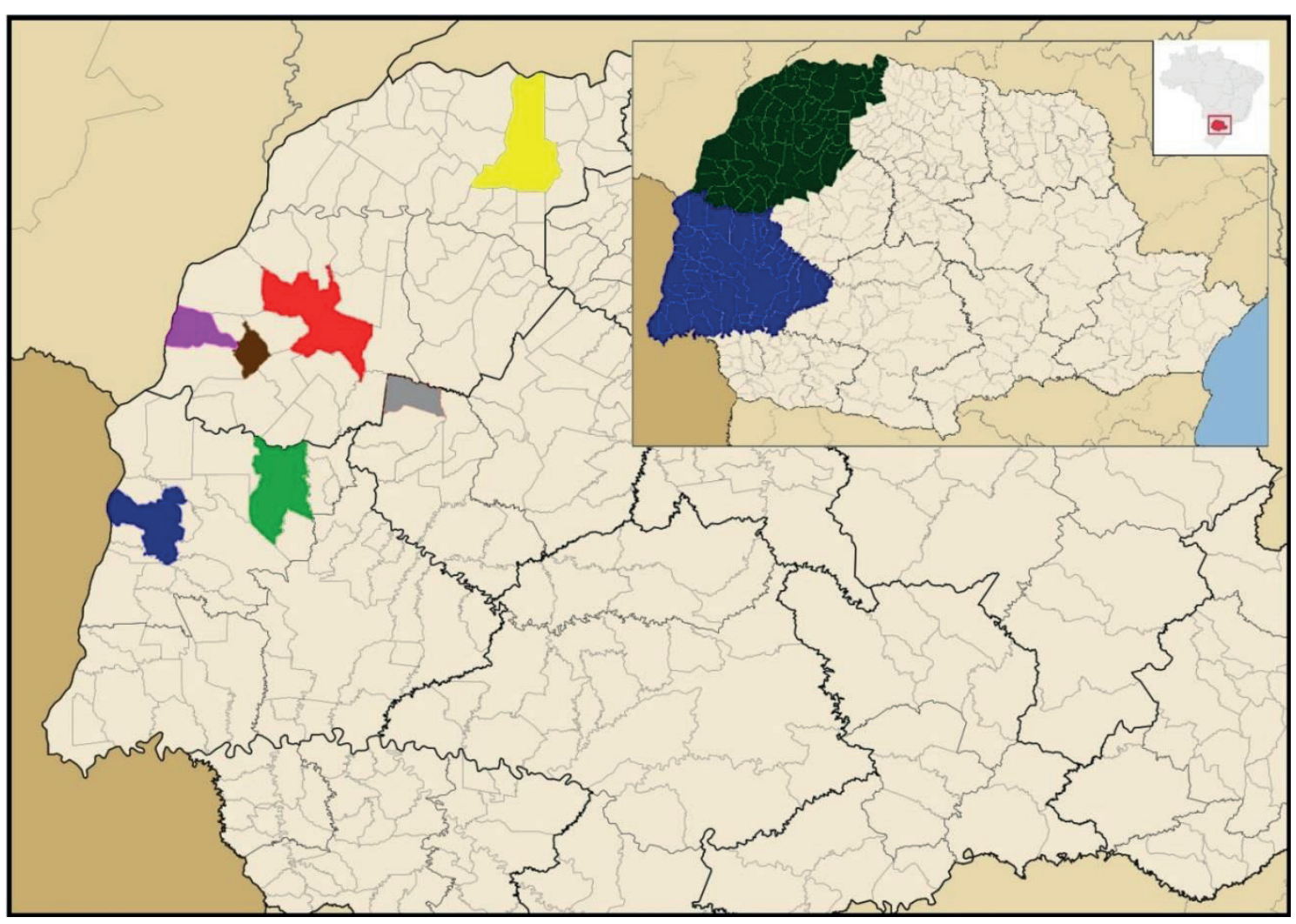

The cities are colored as follows: Assis Chateaubriand (green); Marechal Cândido Rondon (blue); Moreira Sales (gray); Paranavaí (yellow); Pérola (brown); São Jorge do Patrocínio (purple); Umuarama (red). 
The collection of blood samples was performed between March and October 2015, through jugular vein puncture. Sera were collected from 181 asymptomatic mongrel stray dogs (49 males and 132 females) with ages ranging from five months to six years.

Each sample was divided into three aliquots of equal volume and stored in sterile containers at $-20^{\circ} \mathrm{C}$.

\section{Diagnoses performed}

To detect anti-Leptospira spp. antibodies, the sera were submitted to the microscopic agglutination test RYU, (1970), using 22 reference serovars: Australis, Bratislava, Autumnalis, Butembo, Fortbragg, Castellonis, Bataviae, Canicola, Whitcombi, Cinoptery, Grippotyphosa, Hebdomadis, Copenhageni, Icterohaemorrhagiae, Panama, Pomona, Pyrogenes, Hardjo, Wolffi, Shermani, Tarassovi, and Sentot, and incubated at $28^{\circ} \mathrm{C}$ for 5 to 10 days in modified EMJH medium (ALVES et al., 1996). Serum samples presenting at least 50\% leptospira agglutinated in a 1:100 dilution were considered positive, and were further diluted two-fold to determine the maximum positive dilution. The analysis considered the serovar presenting the highest agglutinating titer as the most wits possibility of being positive, while those presenting co-agglutination in the highest dilution were considered positive for Leptospira spp. (FÁVERO et al., 2002).

To detect anti- $B$. canis antibodies, the sera were submitted to an agar gel immunodiffusion test (AGID), using commercial kits including antigens (protein and lipopolysaccharides) from B. ovis and REO 198 sample (produced by the Technology Institute of Paraná). Samples were considered positive if a precipitation line was present between the test serum and antigen wells, according to the manufacturer's instructions.

To detect anti- $T$. gondii antibodies, the sera were submitted to an indirect immunofluorescence assay (CAMARGO, 1973), using a commercial anti-human $\mathrm{IgG}$ conjugate. The sera were tested in sequential four-fold dilutions up to 1:4096, and those presenting fluorescent tachyzoites with a titer $\geq 16$ were considered positive.

\section{Results}

The number of stray dogs studied in each city was: Assis Chateaubriand, 35; Marechal Cândido Rondon, 49; Moreira Sales, 15; Paranavaí, 21; Pérola, 23; São Jorge do Patrocínio, 23; and Umuarama, 15.

For toxoplasmosis, $36.46 \%$ of samples were positive by IIF, with titers ranging from 16 to 4096, with higher prevalence in female dogs $(75.76 \%$; Tables 1 and 2).

Table 1. Anti-Toxoplasma gondii, anti-Leptospira spp., and anti-Brucella canis antibodies in relation to the sex of 113 stray dogs (Paraná, 2015).

\begin{tabular}{ccccc}
\hline Sex & $\begin{array}{c}\text { Anti- } \\
\text { Toxoplasma gondii }\end{array}$ & $\begin{array}{c}\text { Anti- } \\
\text { Brucella canis }\end{array}$ & $\begin{array}{c}\text { Anti- } \\
\text { Leptospira spp. }\end{array}$ & Total \% \\
\hline Female & 50 & 10 & 21 & 71.68 \\
Male & 16 & 7 & 9 & 28.32 \\
Total & 66 & 17 & 30 & 113 \\
\hline
\end{tabular}


For leptospirosis, 30 animals (16.57\%) of samples were positive by MAT, presenting titers ranging from 100 to 6400, and of these, (Table 1). In $93.34 \%$ of samples, it was possible to identify the antibody against the most probable serovar, with Canicola being the most prevalent (in 50\% of samples), followed by Butembo (37.71\%),
Grippotyphosa (7.14\%), and Pomona and Fortbragg (3.5\% each) (Tables 1 and 3$)$.

For B. canis, $9.39 \%$ of the samples were positive by AGID. Antibodies were most prevalent in females, detected in $58.82 \%$ of the samples (Tables 1 and 2).

Table 2. Results from indirect immunofluorescence (IIF), microscopic seroagglutination test (MAT), and agar gel immunodiffusion (AGID) of samples from 181 stray dogs (Paraná, 2015).

\begin{tabular}{ccccccc}
\hline City & $\begin{array}{c}\text { Total } \\
\text { Sample N }\end{array}$ & $\begin{array}{c}\text { IIF } \\
\text { Toxoplasmosis }\end{array}$ & $\begin{array}{c}\text { AGID } \\
\text { Brucellosis }\end{array}$ & $\begin{array}{c}\text { MAT } \\
\text { Leptospirosis }\end{array}$ & $\begin{array}{c}* \% \\
\text { Shelter }\end{array}$ & $\begin{array}{c}* * \% \\
\text { total }\end{array}$ \\
\hline Assis Chateaubriand & 35 & 5 & 4 & 1 & 25.57 & 20 \\
Marechal Cândido Rondon & 49 & 15 & 2 & 6 & 43.94 & 28 \\
Moreira Sales & 15 & 6 & - & 7 & 86.66 & 9 \\
Paranavaí & 21 & 11 & 3 & 4 & 85.71 & 10 \\
Pérola & 23 & 10 & 5 & 2 & 73.9 & 13 \\
São Jorge do Patrocínio & 23 & 11 & 3 & 6 & 86.95 & 13 \\
Umuarama & 15 & 8 & - & 4 & 80 & 7 \\
Total & 181 & 66 & 17 & 30 & & 113 \\
\hline
\end{tabular}

*Percentage represents the number of positive samples in relation to the number of samples per shelter.

**Percentage represents the number of positive samples by shelter in relation to the total samples analyzed.

Table 3. Antibodies against the most probable serovars detected by the microscopic seroagglutination test (MAT) in 28 blood samples from stray dogs (Paraná, 2015).

\begin{tabular}{cccccc}
\hline \multirow{2}{*}{ City } & \multicolumn{5}{c}{ Antibody against most probable serovar } \\
\cline { 2 - 6 } & Canicola & Butembo & Grippotyphosa & Pomona & Fortbragg \\
\hline Assis Chateaubriand & - & - & 1 & - & - \\
Marechal Cândido Rondon & 1 & 4 & - & - & 1 \\
Moreira Sales & 2 & 4 & - & - & - \\
Paranavaí & 2 & 2 & - & - & - \\
Pérola & 1 & - & - & 1 & - \\
São Jorge do Patrocínio & 4 & - & - & - & - \\
Umuarama & 4 & 35.71 & 7.14 & 3.57 & 1 \\
\% total & 50.00 & 10 & 2 & 1 &
\end{tabular}

\section{Discussion}

Owing to their contact with humans, the incubation periods of different diseases, and the possibility of asymptomatic cases, dogs play an important role in the maintenance of different infectious and parasitic diseases in the environment. Possible transmission to humans poses a public health concern, especially in relation to stray dogs (DREER et al., 2013).

A point of concern that must be made in relation to stray dogs in shelters is that toxoplasmosis, leptospirosis, and brucellosis are considered occupational diseases; that is, they are associated with workers who are frequently exposed to 
possibly infected animals and their waste. Based on this research, the awareness of shelter employees will be very important from a health perspective.

Of the 181 samples analyzed, $36.46 \%$ (66/181) were considered positive for toxoplasmosis; there was greater prevalence in females $(30.3 \%)$ than in males (9.7\%). Coiro et al. (2011) observed that female animals presented a 1.6 greater chance of infection than male animals. However, other reports have indicated no significant differences between male and female animals (ULLMANN et al., 2008).

Since toxoplasmosis is a globally distributed disease, transmitted in several ways among animals and humans, personal and food hygiene habits must be prioritized in the prevention and control of this infection.

Bresciani et al. (2008) noted a higher percentage of toxoplasmosis-positive dogs among those with access to the street, compared to housebound dogs.

Moura et al. (2009) analyzed 400 samples in the cities of Lages and Balneário Camboriú in the state of Santa Catarina to detect T. gondii, and 89 (22.3\%) were positive, including $52(26 \%)$ in Lages and 37 (18.5\%) in Balneário Camboriú. Since it is a cosmopolitan parasite, this protozoan is found in different geographic regions, and can present quite variable prevalence indexes.

Studies performed in other Brazilian states have demonstrated high toxoplasmosis indexes, such as Mato Grosso (88.5\%); Santos et al. (2009) and Pernambuco (57.6\%), (FIGUEREDO et al., 2008). In the northwestern region of the state of Paraná, Dreer et al. (2013) found that $70.85 \%$ of animals were positive for toxoplasmosis, a higher index than the one found in this study $(36.46 \%)$.

Certain canine habits, including rolling in or ingesting cat feces containing $T$. gondii oocysts, increase the risks of infection and domestic environment contamination, exposing their owners to toxoplasmosis (LANGONI et al., 2006); therefore, dogs may act as mechanical transmitters of this parasite.
Dogs are considered sentinels for environmental contamination by $T$. gondii, and the $36.46 \%$ prevalence shows that this parasite is broadly distributed in this region. This is alarming and worrying for public health, since the sheltered dogs have direct contact with the people responsible for the shelters, as well as visitors, and many of them have access to the city streets. Additionally, every day, more animals suffering ill treatment and abandonment are sheltered, including animals with large numbers of pups. The presence of horses, cows, and cats in the same environment can ease the dissemination of the disease and consequent infection in the exposed population.

For leptospirosis, the prevalence was $16.57 \%$ in this study, higher than that detected by Morikawa (2010), who found that $9.2 \%$ of dogs in the city of Curitiba (Paraná) were positive, and lower than that detected by Bier et al. (2013), who found a prevalence of $27.8 \%$ in a different region of Curitiba (Paraná). The latter studied a region without basic sanitation with a history of flooding, favoring the existence of rodents.

A few studies have noted that the Canicola and Icterohaemorrhagiae serovars are traditionally associated with leptospirosis in dogs not only in Brazil, but also in other countries (QUERINO et al., 2003). This study did not detect antibodies against the Icterohaemorrhagiae serovar, but antibodies against Canicola were the most frequently detected, in approximately $50 \%$ of the samples. This result does is similar to the results of with the work by Silva-Zacarias et al. (2014), who detected a prevalence of $33.33 \%$ for the Canicola serovar in the city of Bandeirantes, in the northern region of Paraná.

The fact that the antibody against the Canicola serovar is the most frequent in this study raises concern, in that dogs may be an important source of infection for humans and other domestic animal species in the areas studied. It is also important to consider that stray dogs are probably not vaccinated against leptospirosis, they drink standing water, and 
go through garbage searching for food that may be contaminated with urine infected by Leptospira spp. (BIER et al., 2013), factors that can expose both humans and animals to infection.

According to Vasconcellos (1993), the infected but asymptomatic dog, which can eliminate viable leptospira through its urine in an intermittent manner over long periods, can be considered responsible for the persistence of leptospira in dogs and humans, and is considered an environmental maintenance source for the etiological agent.

Antibodies against the Pomona and Fortbragg serovars, the prevalence of which have not been previously reported in the literature, were both detected at $3.57 \%$ in this study. These serovars may be associated with the close relationship of these sheltered dogs with other sheltered animals, such as horses, cows, birds, cats, and sheep (MORIKAWA, 2010). However, as these animals have lived in the streets for long periods, exposed to different sources of infection, the cause of these specific infections cannot be known.

Some studies have suggested a higher prevalence of leptospirosis in female dogs, while others have described this in male dogs. However, these reports have not provided causative reasons, making male or female animals more or less predisposed (BATISTA et al., 2004b; ASLANTA et al., 2005; SILVA-ZACARIAS et al., 2014). Differences in seropositivity may be due to different behavioral reflexes, as males have the habit of sniffing several surfaces in order to recognize a territory, with their noses potentially in contact with locations contaminated with the etiological agent (CALDAS et al., 1976).

For brucellosis, the antibody prevalence was $9.39 \%$, with ten $(58.82 \%)$ female against seven $(41.18 \%)$ male animals infected. Moraes et al. (2002) observed no difference in the proportion of samples positive for canine brucellosis, with male and female animals being equally susceptible.

In this study, the cities presenting the highest prevalence of brucellosis were Pérola and Assis Chateaubriand. Little has been done to control canine brucellosis in a systematic manner in Brazil, other than in a few commercial kennels. Many $B$. canis cases are not reported, mainly because notification is not mandatory. Therefore, all small animal veterinarians, as well as dog and cat owners, must be vigilant in order to prevent this disease from affecting other animals.

Canine brucellosis has been found in Americas, Europe, Asia, and Africa (CARMICHAEL, 1990). In Brazil, serological studies in dogs have shown B. canis infection prevalence ranging from $0.84 \%$ (MORAES et al., 2002) to 58.3\% (FERREIRA et al., 2003). Studies range from a kennel with infected animals to prevalence surveys in pets or stray dogs (MIRANDA et al., 2005).

Almeida et al. (2004) analyzed serum samples from 635 dogs in Alfenas and the prevalence of $B$. canis was $14.2 \%(90 / 635)$, while for $B$. abortus it was $18.1 \%$ (115/635). Dreer et al. (2013) analyzed 175 serum samples from stray dogs from shelters in the northwestern region of Paraná, and found that $2.85 \%$ of samples were positive for $B$. canis.

The data obtained for B. canis in this study are compatible with those found in both the Brazilian and international literature, which show prevalence between 0.84 (MORAES et al., 2002) and 57.1\% (MEGID et al., 1999). For B. abortus, the literature also presents low prevalence indices, with Molnar et al. (2001) having observed a prevalence of $2.5 \%$. In Salvador (BA), $4.6 \%$ of dogs from a low-income human population were positive for antibodies against $B$. canis in an indirect enzyme-linked immunosorbent assay (JESUS et al., 2006).

Vargas et al. (1996), surveying a kennel in the city of Uruguaiana (RS), found $72.70 \%(8 / 11)$ seropositivity by the AGID test, a high prevalence in relation to that in the northwestern region of the state of Paraná.

There is little epidemiological data available on B. canis in Brazil, owing to the difficulty in 
establishing final diagnosis. Kennel owners are not used to adopting prevention and control measures, and may be either unaware of the disease or consider brucellosis to be of low importance (MALEK et al., 2008).

Seroprevalence studies in dogs have shown that the disease is frequent in locations with a high density of free-roaming dogs and in kennels that do not adopt control measures. $B$. canis can infect other animal species, such as production animals living closely with dogs on rural properties, disseminating the disease to the human population, but few studies have examined the distribution of infection (FERREIRA et al., 2003).

Zoonotics are characterized as occupational diseases, increasing the risk of several diseases in animal health professionals, mainly those with direct contact with animals or indirect contact through biological materials of animal origin. Additionally, these diseases are relevant for both public health and for economic matters, since they generate costs to the public health network, including emergencies, hospitalizations, deaths, and absence from work. Thus, it is important to understand their means of contamination and infection, and develop guidelines for their prevention and control (DIAS, 2012).

It is important that both authorities and the entire population be aware of these zoonotic diseases and their high prevalence in the northwestern region of the state of Paraná, since they are risks to the health of both animals and humans. Health educational programs will be necessary for the general population, since these animals are destined for adoption and could expose their future families to the risk of a zoonotic infection.

\section{Ethical Aspects}

The Committee of Ethics in Research Involving Animal Experimentation(CEPEEA) at Universidade Paranaense (UNIPAR) approved the project, under protocol 28.149 on $04 / 12 / 2014$.

\section{Acknowledgments}

The authors would like to thank UNIPAR for the funding granted to this research and the granting of PIBIC and PIT scholarships, and the Department of Preventive Veterinary Medicine at State University of Londrina (UEL) for performing the laboratory exams.

\section{References}

ALMEIDA, A. C.; SANTORELLI, A.; BRUZADELLI, R. M. Z.; OLIVEIRA, M. M. N. F. Soroepidemiologia da brucelose canina causada por Brucella canis e Brucella abortus na cidade de Alfenas, MG. Arquivo Brasileiro de Medicina Veterinária e Zootecnia, Belo Horizonte, v. 56, n. 2, p. 275-276, 2004.

ALVES, C. J.; VASCONCELLOS, S. A.; CAMARGO, C. R. A.; MORAIS, Z. M. Influência de fatores ambientais sobre a proporção de caprinos soro-reatores para Leptospirose em cinco Centros de Criação do Estado da Paraíba, Brasil. Biológico, São Paulo, v. 63, n. 2, p. 11-18, 1996.

ARAÚJO, D. A.; SILVA, A. V.; ZANETTE, D. F.; CORREA, N. A. B.; VELASQUEZ, L. G.; PINTONETO, A. Investigação dos fatores associados à infecção pelo Toxoplasma gondii em cães e seres humanos de Porto Figueira, PR. Veterinária e Zootecnia, Botucatu, v. 18, n. 1, p. 98-111, 2011.

ASLANTA, O.; OZDEMIR, V.; KILIÇ, S.; BABUR, C. Seroepidemiology of leptospirosis, toxoplasmosis, and leishmaniosis among dogs in Ankara, Turkey. Veterinary Parasitology, Amsterdam, v. 129, n. 2, p. 187-191, 2005.

AZEVEDO, S. S.; VASCONCELLOS, S. A.; KEID, L. B.; GRASSO, L. M. P. S.; PINHEIRO, S. R.; MASCOLLI, R.; ALVES, C. J. Comparação de três testes sorológicos aplicados ao diagnóstico da infecção de caninos por Brucella Canis. Brazilian Journal of Veterinary Reserach and Animal Sciene, São Paulo, v. 41, n. 2, p. 106-112, 2004.

BATISTA, C. S. A.; AZEVEDO, S. S.; ALVES, C. J.; VASCONCELLOS, S. A.; MORAIS, Z. M.; CLEMENTINO, I. J.; LIMA, F. S.; ARAÚJO-NETO, J. O. A. Soroprevalência de leptospirose em cães errantes da Cidade de Patos, Estado da Paraíba, Brasil. Brazilian Journal of Veterinary Research and Animal Science, São Paulo, v. 41, n. 2, p. 131-136, 2004a.

BATISTA, C. S. A.; VASCONCELLOS, S. A.; MORAIS, Z. M.; CLEMENTINO, I. J.; ALVES, F. A. L; LIMA, F. S; ARAÚJO NETO, J. O. Soroprevalência e fatores de risco 
para a leptospirose em cães de Campina Grande, Paraíba. Arquivo Brasileiro Medicina Veterinária Zootecnia, Belo Horizonte, v. 57, n. 2, p. 179-185, 2004b.

BIER, D.; SHIMAKURA, S. E.; MORIKAWA, V. M.; ULLMANN, L. S.; KIKUTI, M.; LANGONI, H.; BIONDO, A. W.; MOLENTO, M. B. Análise espacial do risco de leptospirose canina na Vila Pantanal, Curitiba, Paraná. Pesquisa Veterinária Brasileira, Rio de Janeiro, v. 33, n. 1, p. 74-79, 2013.

BLAZIUS, R. D.; ROMÃO, P. R. T.; BLAZIUS, E. M. C. G.; SILVA, O. S. Ocorrência de cães errantes soropositivos para Leptospira spp. na Cidade de Itapema, Santa Catarina, Brasil. Cadernos de Saúde Pública, Rio de Janeiro, v. 21, n. 6, p. 1952-1956, 2005.

BRESCIANI, K. D. S.; COSTA, A. J.; NAVARRO, I. T.; TONIOLLO, G. H.; SAKAMOTO, C.A. M.; ARANTES, T. P.; GENNARI, S. M. Toxoplasmose canina: aspectos clínicos e patológicos. Semina: Ciências Agrárias, Londrina, v. 29, n. 1, p. 189-202, 2008.

CALDAS, E. M.; SAMPAIO, M. B.; BADARO, M. V.; SANTOS, M. D.; TISHCHENKO, L. M. Leptospirose canina: alguns aspectos sorológicos, laboratoriais e clínicos. Arquivos Escola Veterinária UFBA, Salvador, v. 1, n. 3, p. 53-66, 1976.

CAMARGO, M. E. Introdução às técnicas de imunofluorescência. Revista Brasileira de Patologia Clínica, Rio de Janeiro, v. 10, n.2. , p. 143-171, 1973.

CARMICHAEL L.E. Brucella canis. In: NIELSEN, K.; DUNCAN, J. R. (Ed.). Animal Brucellosis. CRC Press, Boca Raton, Florida. 1990. p. 335-350.

CASTRO, J. R.; SALABERRY, S. R. S.; SOUZA, M. A.; LIMA-RIBEIRO, A. M. C. Sorovares de Leptospira spp. predominantes em exames sorológicos de caninos e humanos no município de Uberlândia, Estado de Minas Gerais. Revista da Sociedade Brasileira de Medicina Tropical, Uberaba, v. 44, n. 2, p. 113-124, 2011.

COIRO, C. J.; LANGONI, H.; SILVA, R. C.; ULLMANN, L. S. Fatores de risco para leptospirose, leishmaniose, neosporose e toxoplasmose em cães domiciliados e peridomíciliados em Botucatu - SP. Veterinária e Zootecnia, Botucatu, v. 18, n. 3, p. 393-407, 2011.

DANTAS, S. B. A.; FERNANDES, A. R. F.; SOUZANETO, O. L. S.; MOTA, R. A.; ALVES, C. J.; AZEVEDO, S. S. Fatores de risco para a ocorrência de anticorpos contra Toxoplasma gondii e Neospora caninum em cães domiciliados no Nordeste do Brasil. Semina: Ciências Agrárias, Londrina, v. 35, n. 2, p. 875-882, 2014.

DIAS, I. S. Prevenção de zoonoses ocupacionais em abatedouros de bovinos. Vivências: Revista Eletrônica de Extensão da URI, Erechim, v. 8, n. 15, p. 89-98, 2012.
DREER, M. K. P.; GONÇALVES, D. D.; CAETANO, I. C. S.; GERÔNIMO, E.; MENEGAS, P. H.; BERGO, D.; LOPES-MORI, F. M. R.; BENITEZ, A.; FREITAS, J. C.; EVERS, F.; NAVARRO, I. T.; MARTINS, L. A. Toxoplasmosis, leptospirosis and brucellosis in stray dogs housed at the shelter in Umuarama municipality, Paraná, Brazil. Journal of Venomous Animals and Toxins including Tropical Diseases, Botucatu, v. 19, n. 25, p. 7782, 2013.

FAVERO,A.C.M.;PINHEIRO,S.R.; VASCONCELLOS, S. A.; MORAIS, Z, M.; FERREIRA, F.; FERRERIA NETO, J. S.; Sorovares de leptospiras predominantes em exames sorológicos de bubalinos, ovinos, caprinos, eqüinos, suínos e cães de diversos estados brasileiros. Ciência Rural, Santa Maria, v. 32, n. 4, p. 613-619, 2002.

FERREIRA, T.; GOMES, M. P. J.; RONCONI, M. A.; AQUINO, M. H. C.; TORRES, H. M.; MANDELBAUM, M. A.; FIGUEIREDO, M. J. Brucelose canina: ocorrência em um canil comercial. Revista Brasileira de Reprodução Animal, Belo Horizonte, v. 27, n. 3, p. 555-556, 2003.

FIGUEREDO, L. A.; DANTAS-TORRES, F.; FARIA, E. B.; GONDIM, L. F. P.; SIMÕES-MATTOS, L.; BRANDÃO-FILHO, S. P.; MOTA, R. A. Occurrence of antibodies to Neospora caninum and Toxoplasma gondii in dogs from Pernambuco, Northeast Brazil. Veterinary Parasitology, Amsterdam, v. 157, n. 1-2, p. 9-13, 2008.

GENOVEZ, M. E. Leptospirose em cães. Clínica Veterinária, São Paulo v. 1, n. 1, p. 6-9, 1996.

JESUS, E. E. V.; SANTOS, P. O. M.; BARBOSA, M. V. F.; PINHEIRO, A. M.; GONDIM, L. F. P.; GUIMARÃES, J. E.; ALMEIDA, M. A. O. Frequência de anticorpos antiNeospora caninum em cães nos municípios de Salvador e Lauro de Freitas da Bahia-Brasil. Brazilian Journal of Veterinary Research and Animal Science, São Paulo, v. 43, n. 2, p. 5-10, 2006.

LANGONI, H.; MODOLO, J. R.; PEZERICO, S. B. Serological profile of anti- Toxoplasma gondii in apparently healthy dogs of the city of Botucatu, São Paulo State, Brazil. Journal of Venomous Animals and Toxins including Tropical Diseases, Botucatu, v. 12, n. 1, p. 142-148, 2006.

MALEK, R. C. B.; HOFFMANN, R. C.; SANTOS, R. S.; TURRI, R. J. G.; ORIANI, M. R. G. Pesquisa de Anticorpos anti-Brucela canis e anti-Brucela abortus em cães errantes da cidade de São João da Boa Vista, SP, Brasil. Brazilian Journal of Veterinary Research and Animal Science, São Paulo, v. 45, n. 1, p. 32-43, 2008.

MAGALHÃES, D. F.; SILVA, J. A.; MOREIRA, E. C.; WILKE, V. M. L.; NUNES, A. B. V.; HADDAD, J. P. A.; MENESES, J. N. C. Perfil dos cães sororreagentes para aglutininas anti-Leptospira interrogans em Belo 
Horizonte, Minas Gerais, 2001/2002. Arquivo Brasileiro de Medicina Veterinária e Zootecnia, Belo Horizonte, v. 59, n. 5, p. 1326-1329, 2007.

MAGALHÃES, R.; MATEUS, T. Desparasitação interna de cães - o que sabem os proprietários de Ponte de Lima. Acta Parasitológica Portuguesa, Porto, v. 19, n. 2, p. 3134, 2012.

MEGID, J.; BRITO, A. F.; MORAES, C. C. G.; FAVA, N.; AGOTTANI, J. Epidemiological assessment of canine brucellosis. Arquivo Brasileiro de Medicina Veterinária e Zootecnia, Belo Horizonte, v. 51, n. 5, p. 439-440, 1999.

MIRANDA, K. L.; COTTORELlO, A. C. P.; POESTER, F. P.; LAGE, A. P. Brucelose canina. Cadernos Técnicos de Veterinária e Zootecnia, Belo Horizonte, v. 47, n. 5, p. 66-82, 2005.

MOLNAR, L.; MOLNAR, E.; CARVALHO, M. Capacidade de algumas provas sorológicas no diagnóstico de brucelose canina. Hora Veterinária, Porto Alegre, v. 21, n. 4, p. 45-49, 2001.

MORAES, C. C. G.; MEGID, J.; SOUZA, L. C.; CROCCI, A. J. Prevalência de brucelose canina na microrregião da Serra de Botucatu, São Paulo, Brasil. Arquivos do Instituto Biológico, São Paulo, v. 69, n. 3, p. 7-10, 2002.

MORIKAWA, V. M. Estudo sorológico da infecção por Leptospira spp. em uma área de ocupação irregular e de alto risco para a doença em cães em Curitiba, PR. 2010. Dissertação (Mestrado em Ciências Veterinárias) Universidade Federal do Paraná, Curitiba.

MOURA, A. B.; SOUZA, A. P.; SARTOR, A. A.; BELLATO, V.; TEIXEIRA, E. B.; PISETTA, G. M.; HEUSSER-JUNIOR, A. H. Ocorrência de anticorpos e fatores de risco para infecção por Toxoplasma gondii em cães, nas cidades de Lages e Balneário Camboriú, Santa Catarina, Brasil. Revista Brasileira de Parasitologia Veterinária, Jaboticabal, v. 18, n. 3, p. 52-56, 2009.

OLIVEIRA, M.; GIRALDO, C. A.; DI-LOREZO, C. Identificación por PCR de Brucella canis em sangre y leche canino. Reporte de Caso. Archivos de Medicina Veterinaria, Valdivia, v. 43, n. 21, p. 255-298, 2011.

QUERINO, A. M. V.; DELBEM, A. C. B.; OLIVEIRA, R. C.; SILVA, F. G.; MULLER, R. L. F.; FREITAS, J. C. Fatores de risco associados à leptospirose em cães do município de Londrina- PR. Semina: Ciências Agrárias, Londrina, v. 24, n. 1, p. 27-34, 2003.

RYU, E. Rapid microscopic agglutination test for leptospira without non-specificreaction. Bulletin Office of International Epizooties, Paris, v. 73, n. 9, p. 49-58, 1970.
SANTOS, T. R.; COSTA, A. J.; TONIOLLO, G. H.; LUVIZOTTO, M. C. R.; BENETTI, A. H.; SANTOS, R. R.; MATTA, D. H.; LOPES, W. D. Z.; OLIVEIRA, J. A.; OLIVEIRA, G. P. Prevalence of anti-Toxoplasma gondii antibodies in dairy cattle, dogs, and humans from the Jauru micro-region, Mato Grosso state, Brazil. Veterinary Parasitology, Amsterdam, v. 161, n. 3-4, p. 324-326, 2009.

SILVA, A. V.; GONÇALVES, G. F.; LÍVERO, F. A. R.; BOTTIN, J. M. P.; BELINATO, F. C.; BASTOSJUNIOR, E. A. B.; SILVA, R. C.; LANGONI, H. Avaliação de fatores epidemiológicos na ocorrência de anticorpos contra Toxoplasma gondii em cães atendidos em um Hospital Universitário. Veterinária e Zootecnia, Botucatu, v. 16, n. 1, p. 239-247, 2009.

SILVA-ZACARIAS, F. G.; MARQUES, D. R. C.; CARDOSO, M. J. L.; FREITAS, J. C.; ZACARIAS JUNIOR, A.; ZAMARIAN, T. P. Frequência de anticorpos anti-Leptospira spp. em cães atendidos no Hospital Veterinário da Universidade Estadual do Norte do Paraná - UENP. Arquivo Ciência Veterinária e Zoologia UNIPAR, Umuarama, v. 17, n. 2, p. 91-95, 2014.

SOUZA PINTO, A. R.; PEREIRA, M. J. S.; ALMOSNY, N. R. P.; ALMEIDA, N. C. A. Análise multivariada dos fatores de risco associados á infecção por Toxoplasma gondii em cães atendidos na Policlínica da Universidade Federal Fluminense. In: CONGRESSO BRASILEIRO DE PARASITOLOGIA VETERINÁRIA, 13., 2004, Ouro Preto. Anais... Ouro Preto: Colégio Brasileiro de Parasitologia Veterinária, Jaboticabal, 2004, p. 215-216.

ULLMANN, L. S.; GUIMARÃES, F. F.; FOMAZARI, F.; TOMÉ, R. O.; CAMOSSI, L. G.; GRECA, H.; SILVA, R. C.; MENOZZI, B. D.; LANGONI, H. Ações de vigilância continuada, papel do cão como animal sentinela para toxoplasmose. Revista Brasileira de Parasitologia Veterinária, Jaboticabal, v. 17, n. 1, p. 345 347, 2008.

VALADAS, S.; MINERVINO, A. H.; LIMA, V. M.; SOARES, R. M.; ORTOLANI, E. L.; GENNARI, S. M. Ocorrência de anticorpos anti- Neospora caninum, antiToxoplasma gondii e anti- Leishmania chagasi no soro de cães de Estado do Pará, Amazônia. Brasil. Parasitology Research, Berlin, v. 107, n. 2, p. 453-457, 2010.

VARGAS, A. C.; LAZZARI, A.; DUTRA, V.; POESTER, F. Brucelose canina: relato de caso. Ciência Rural, Santa Maria, v. 26, n. 2, p. 305-308, 1996.

VASCONCELLOS, S. A. Leptospirose animal. In: ENCONTRO NACIONAL EM LEPTOSPIROSE, 3., 1993, Rio de Janeiro. Anais... Rio de Janeiro: Ministério da Saúde/Instituto Oswaldo Cruz/Fundação Nacional de Saúde, 1993. p. 62-65. 